\title{
ANALISIS EFISIENSI SALURAN PEMASARAN KARET RAKYAT DI JAMBI \\ (Studi Kasus Desa Panerokan, Kecamatan Bajubang, Kabupaten \\ Batanghari, Provinsi Jambi)
}

\begin{abstract}
Ahmad Tarmizi *)
Abstract

The purpose of the research is to know the distribution of people rubber trading that more efficiency at Desa Panerokan. The place of research at Desa Panerokan, Kecamatan Bajubang, Kabupaten Batang Hari. The sample uses the purposive sample method. Trading margin analysis is used to know the efficiency level of trading distribution. The result of research show there are two trading distribution: 1) KUD/Auction market; 2) traditional trader KUD/Auction market has 60,2\% rubber of rubber farmer, mean while, traditional trader has 39,8\% rubber of farmer. The price of KUD/Auction market is higher than the traditional trader. Netto income of auction player is $R p .300$ per $\mathrm{kg}$ dried rubber, while netto income traditional trader is smaller about Rp. 150 per $\mathrm{kg}$ dried rubber
\end{abstract}

Keywords: rubber, distribution of people rubber trading.

\section{Pendahuluan}

Dalam pembangunan saat ini suatu negara tidak mungkin melaksanakan pembangunan yang tertutup. Setiap negara harus mengadakan hubungan perdagangan dengan negara lain. Keseimbangan pembayaran ekspor-impor merupakan indikator keberhasilan dalam mempertahankan tingkat pertumbuhan pembangunan. Untuk memenuhi kebutuhan devisa akibat adanya impor baik barang modal, bahan baku dan teknologi dalam upaya melaksanakan pembangunan, maka Indonesia terus melaksanakan pengembangan komoditi ekspor. Salah satu subsektor pertanian yang potensial untuk meningkatkan nilai ekspor Indonesia adalah perkebunan.

Beberapa komoditi perkebunan di Indonesia perkembangannya terus digalakkan baik luas areal perkebunan maupun produktifitasnya. Potensi lahan kering untuk perluasan area pertanian tanaman pangan dan perkebunan cukup luas yaitu mencapai 34 juta hektar yang di Kalimantan, Sulawesi dan Irian Jaya (Suhaedi, 1986). 
Indonesia saat ini merupakan negara produsen utama karet alam dunia, dengan kebun terluas di dunia yakni 3,3 juta hektar dan produksi urutan kedua di dunia yakni 2,7 juta ton di bawah Thailand 3,7 juta ton dengan luas kebun hanya 2,1juta hektar (Arbain, 2007). Karet alam merupakan salah satu hasil perkebunan Indonesia yang nilai ekspornya terus berkembang. Tanaman karet dapat tumbuh baik di Indonesia, terutama di daerah-daerah yang dapat tumbuh dengan baik khususnya yang menyangkut kesesuaian lahan, ketinggian, keadaan iklim, kelembaban dan suhu.

Tingkat produktivitas karet rakyat yang sangat rendah hanya $796 \mathrm{~kg}$ perha/tahun, sedangkan Thailand bisa $1.688 \mathrm{~kg}$ per-ha/tahun ini disebabkan karena sebagian besar tanaman yang ada sudah tua dan rusak (Arbain,2007). Produktivitas karet rakyat yang rendah di beberapa daerah biasanya diikuti oleh rendahnya mutu bokar (bahan olah karet) yang dihasilkan. Rendahnya mutu bokar pada akhirnya memperbesar biaya pengangkutan, pembersihan dan penyeragaman mutu bagi pihak prosesor. Sehingga harga yang diperoleh petani akan menjadi kecil.Selain itu sistem pemasaran bahan olahan karet rakyat dari petani produsen ke pihak prosesor di Indonesia masih kondisi yang belum efisien. Hal ini dapat dilihat dari rantai pemasaran bokar rakyat yang panjang dan bertingkat-tingkat.

Pendistribusian produk ke konsumen memerlukan saluran untuk memperlancar penyampaian dan untuk memastikan bahwa produk berada di tempat yang sesuai. Menempatkan ditempat yang tepat dapat merangsang pembelian. Saluran untuk menyampaikan produk ke konsumen dikenal dengan istilah saluran distribusi atau saluran pemasaran.

Suatu kegiatan pemasaran dikatakan efisien apabila kegiatan ini dapat memberikan balas jasa yang simbang kepada semua pihak yang terlibat, yaitu produsen, pedagang perantara dan konsumen akhir (Azzaino, 1981). Menurut Dahl dan Hammond (1987), efisiensi pemasaran secara umum dapat dibedakan atas efisiensi operasional dan efisiensi harga . Efektifitas mengacu kepada bagaimana tujuan distribusi dapat diselesaikan dengan baik, sedangkan efisiensi mengacu 
kepada penyelesaian tugas pendistribusian dengan sumber daya yang sekecilkecilnya (Bowersox dan Cooper, 1992)

Produk pertanian merupakan salah satu contoh daur hidup produk yang umumnya pendek merupakan kendala tersendiri bagi produsen. Produsen dihadapkan pada masalah keuntungn dan resiko yang dihadapi jika tidak segera dipasarkan maka produk tersebut akan rusak dan tidak dapat dimanfaatkan lagi. Sementara itu harga produk tersebut seringkali tidak dapat menutupi biaya-biaya yang telah dikeluarkan oleh produsen dalam menghasilkan produknya, akibatnya produsen mengalami kerugian.

Selama ini petani menjual karetnya ke saluran - saluran yang sudah ada dan hal ini sudah berlangsung selama bertahun - tahun. Karet merupakan salah satu potensi andalan bagi Propinsi Jambi. Hal ini karena kualitas karet yang baik dan keadaan iklim serta tanah yang sangat mendukung. Sebagai salah satu potensi yang diandalkan diperlukan suatu keterkaitan yang saling menguntungkan. Artinya bagi pihak- pihak yang terlibat dalam kegiatan produksi dan pemasaran karet tersebut harus saling menguntungkan.

Tujuan penelitian adalah : "Untuk mengetahui saluran pemasaran karet rakyat yang lebih efisien di Panerokan"

Gambar. 1. Pola umum pemasaran karet rakyat di Jambi

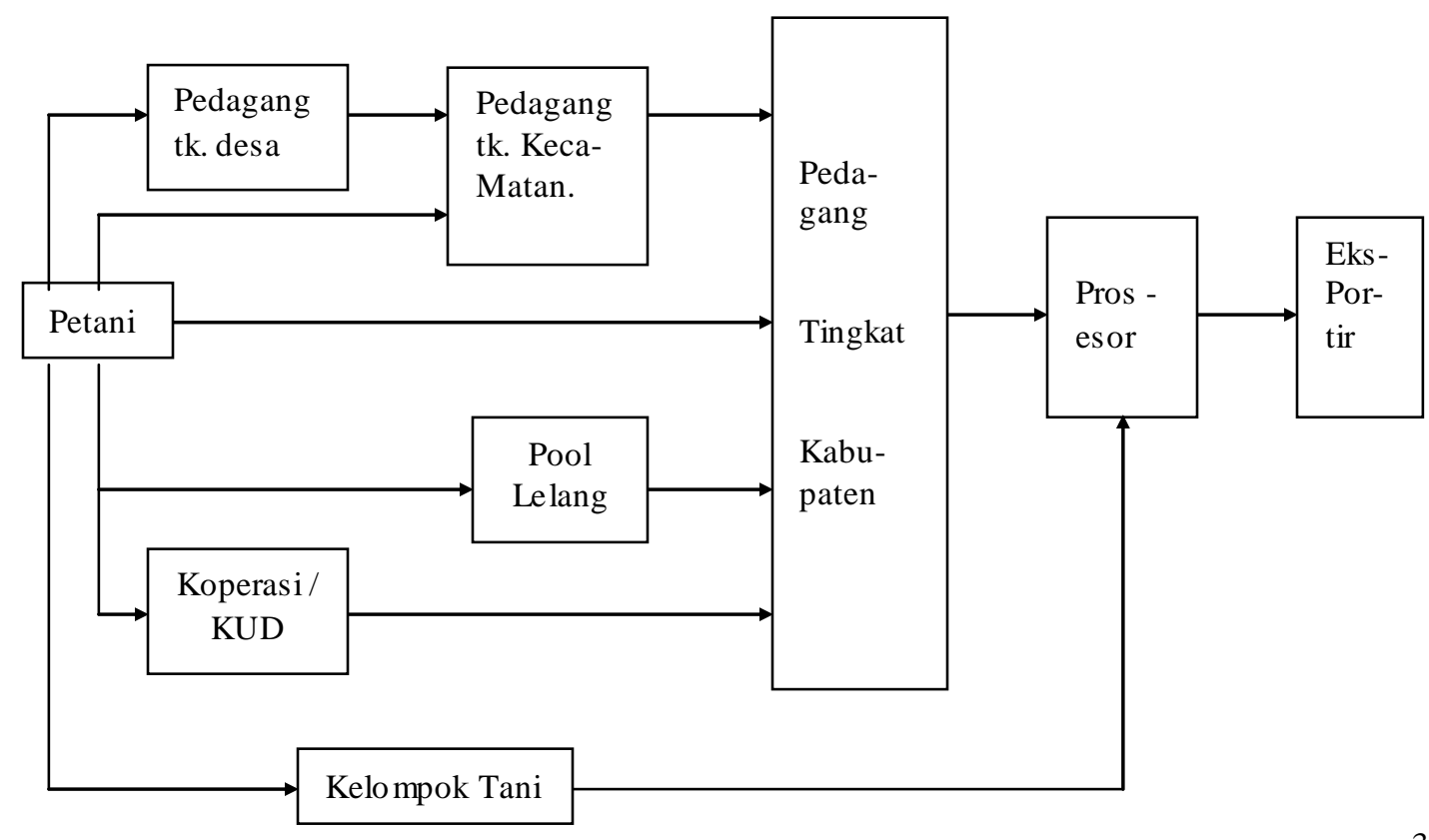




\section{Metode}

Lokasi penelitian berada di Desa Panerokan, Kecamatan Bajubang, Kabupaten Batanghari, Provinsi Jambi. Penarikan sampel menggunakan metode purposive sampling yaitu pemilihan sekelompok subjek didasarkan atas cirri-ciri atau sifat-sifat tertentu yang dipandang mempunyai sangkut paut yang erat dengan ciri-ciri atau sifat-sifat populasi yang sudah diketahui sebelumnya.

\section{Analisis}

Margin pemasaran merupakan perbedaan harga yang diterima oleh petani dengan harga yang dibayarkan oleh suatu lembaga pemasaran untuk suatu jenis mutu tertentu merupakan penjumlahan seluruh biaya pemasaran yang dikeluarkan dengan keuntungan yang diterima lembaga pemasaran.

Untuk menghitung besarnya margin pemasaran digunakan perumusan sebagai berikut:

$$
\begin{aligned}
& \text { Mpi }=\text { Pji }- \text { Pbi } \\
& \text { Mpi }=\text { Bti }+ \text { Kti }
\end{aligned}
$$

Sehingga marjin pemasaran total adalah :

$$
\mathrm{Mp}=\mathrm{Mpi}
$$

Dimana :

Mpi = Margin pemasaran pada tingkat ke i

$\mathrm{Pji}=$ Harga jual pasar tingkat ke $\mathrm{i}$

$\mathrm{Pbi}=$ Harga pembelian pada pasar tingkat ke i

$\mathrm{Kti}=$ Keuntungan lembaga pemasaran pada pasar tingkat ke i

Bti =Biaya pemasaran pada pasar tingkat ke $\mathrm{i}$

$\mathrm{Mp}=$ Margin pemasaran total

I $=1,2,3, \ldots \ldots \ldots . n$

Atau,

$$
\mathrm{Mt}=\mathrm{Hk}-\mathrm{Hp}
$$


Dimana :

$\mathrm{Mt}=$ margin total

$\mathrm{Hp}=$ Harga di tingkat konsumen (prosesor)

$\mathrm{Hk}=$ Harga di tingkat petani

Margin pemasaran dapat dihitung secara absolut dan relatif (\%). Dalam penelitian ini akan di pergunakan kedua cara perhitungan tersebut, dimana harga di tingkat konsumen (prosesor) merupakan harga akhir yaitu 100 persen.

\section{HASIL}

Tanaman karet sudah sejak lama ditanam oleh penduduk desa Panerokan, terutama tanaman karet yang berasal dari biji sapuan sudah ditanam sejak tahun 1950-an. Hingga saat ini pengembangannya terus dilakkukan. Pengembangan bibit unggul, pupuk dan pemeliharaan tanaman karet dilakukan hampir setiap hari. Kepemilikan kebun karet petani rata - rata mencapai 5 - 6 hektar, bahkan ada yang mencapai puluhan hektar. Petani yang memiliki kebun yang luas, umumnya mempunyai tenaga penyadap dengan sistem bagi hasil $1: 2$ = pemilik : penyadap. Petani pemilik kebun umumnya juga merangkap sebagai pedagang bahan olah karet, pedagang bahan kebutuhan pokok, dan pemodal kuat yang dapat meminjamkan uangnya kepada para petani kecil dan penyadap yang membutuhkan. Petani biasanya melakukan penyadapan pada pagi hari sampai menjelang sore hari. Mereka umumnya dapat menghasilkan $15 \mathrm{~kg}$ lateks perhari jika curah hujan cukup. Namun pada musim kemarau mereka hanya dapat menghasilkan rata - rata $8 \mathrm{~kg}$ lateks per hari. Produksi bokar rata - rata desa Panerokan berkisar antara 50 - 70 ton per 2 minggu.

Dari penelusuran arus komoditi karet yang dipasarkan di desa Panerokan mulai dari petani sebagai produsen hingga ke pabrik pengolah sebagai konsumen akhir. Terdapat 2 saluran pemasaran yang melibatkan lembaga-lembaga sebagai berikut : 
Gambar 2 Saluran pemasaran karet di desa Panerokan

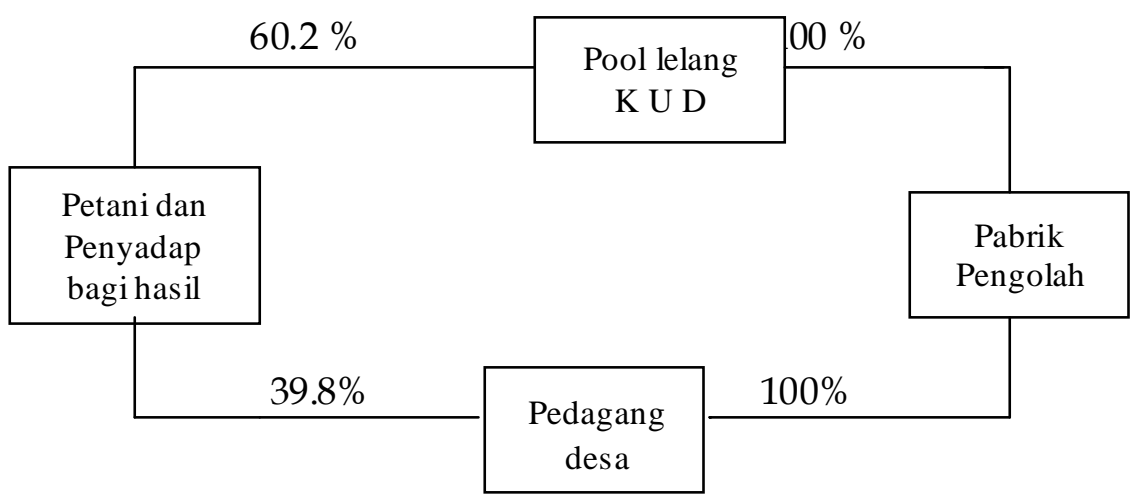

Dari gambar di atas dapat dilihat bahwa pemasaran karet di desa Panerokan yang dapat dibedakan menjadi 2 saluran pemasaran yaitu : 1)saluran KUD/Pasar lelang dan 2)saluran pedagang desa.

Saluran pemasaran yang KUD/Pasar lelang saat ini menyerap $60.2 \%$ hasil karet rakyat, meliputi pola :

a. Petani dan penyadap bagi hasil - Pasar lelang - Pabrik pengolah.

KUD berfungsi sebagai panitia lelang yang menghubungkan petani dan penyadap bagi hasil sebagai peserta lelang dengan pabrik pengolah.

Sedangkan sisanya $(39,8 \%)$ penduduk memasarkan karetnya melalui saluran pedagang desa sebagai berikut :

b. Petani dan penyadap bagi hasil - pedagang desa - pabrik pengolah.

Keberadaan pasar lelang di desa Panerokan tidak terlepas dari adanya permasalahan pada saluran pemasaran karet yang tidak efisien. Salah satu upaya yang dilakukan oleh Pemerintah Daerah Jambi adalah mendirikan pasar lelang karet (PLK).

Salah satu diantaranya adalah PLK Desa Panerokan, Kecamatan Bajubang, Kabupaten Batanghari. PLK Panerokan didirikan dan dikelola oleh KUD Berdikari desa Panerokan pada tahun 1990, sebagai kelanjutan dari pasar lelang yang pernah dibentuk pada tahun 1975, dengan peserta terdiri dari pedagang 
pengumpul ( termasuk KUD) dan pabrik pengolah. Pasar lelang ini tidak berkembang karena :

a. Lokasi yang jauh dari produsen karet

b. Tidak melibatkan produsen (petani) secara langsung

c. Dimungkinkan terjadi usaha manipulasi pedagang untuk memperjual belikan karet olahan milik sendiri.

Sistem saluran pemasaran karet yang disempunakan melalui KUD/Pasar lelang menerapkan standar harga sebagai berikut:

\section{KKK * ( $85 \%$ harga FobSIR 20$)$}

Penentuan mutu karet ditentukan secara visual dengan melihat keadaan karet setelah dibelah. Pemilihan pasar lelang oleh sebagian besar petani dalam memasarkan produknya dikarenakan pasar lelang tidak menerapakan potongan, sehingga penerimaan petanipun menjadi lebih tinggi dibandingkan jika mereka menjual ke saluran pedagang desa.

\section{Analisis Margin Pemasaran Karet.}

Untuk mengetahui saluran mana yang efisien dan menguntungkan bagi petani dalam memasarkan hasil karetnya. Hal ini dapat dilihat pada gambaran mengenai biaya dan keuntungan serta margin dari masing-masing saluran pemasaran yang dapat dilihat pada tabel :

Tabel 1.Margin Saluran Pemasaran KUD/Pasar Lelang.

\begin{tabular}{|l|c|}
\hline \multicolumn{1}{|c|}{ Uraian } & \multicolumn{2}{|c|}{ Rp/Kg } \\
& $\begin{array}{c}\text { Kadar karet Kering } \\
80 \%\end{array}$ \\
\hline Harga jual petani & 6.500 \\
Harga beli cuka getah & 2.500 \\
Margin biaya & 2.500 \\
Margin keuntungan & 4.000 \\
Margin total & 6.500 \\
\hline
\end{tabular}




\begin{tabular}{|l|r|}
\hline Harga jual & 6.500 \\
\hline Harga beli KUD/Lelang & 6.500 \\
\hline Koperasi Unit Desa/Lelang & 6.500 \\
Biaya Transportasi & 0 \\
Biaya bongkar muat & 250 \\
Biaya penyusutan & 100 \\
Biaya administrasi KUD & 50 \\
Margin biaya & 400 \\
Margin Keuntungan & 300 \\
Margin total & 700 \\
Harga Jual & 7.200 \\
\hline Harga beli pabrik & 7.200 \\
\hline
\end{tabular}

Tabel 2. Margin Pemasaran Saluran Pedagang Desa.

\begin{tabular}{|l|r|}
\hline \multicolumn{1}{|c|}{ Uraian } & \multicolumn{2}{|c|}{ Rp/Kg } \\
& \multicolumn{2}{|c|}{ Kadar karet Kering } \\
\hline Harga jual petani & 6.000 \\
Harga beli cuka getah & 2.500 \\
Potongan basi 10\% & 600 \\
Margin biaya & 3.100 \\
Margin keuntungan & 2.900 \\
Margin total & 6.000 \\
Harga jual & 6.000 \\
\hline Harga beli pedagang desa & 6.000 \\
\hline Pedagang desa & 6.000 \\
Biaya Transportasi & 700 \\
Biaya bongkar muat & 250 \\
\hline
\end{tabular}




\begin{tabular}{|l|r|}
\hline Biaya penyusutan & 100 \\
Margin biaya & 1.050 \\
Margin Keuntungan & 150 \\
Margin total & 1.200 \\
Harga Jual & 7.200 \\
\hline Harga beli pabrik & 7.200 \\
\hline
\end{tabular}

\section{Pembahasan}

Dari kedua tabel dapat dilihat bahwa harga yang diterima petani peserta lelang lebih tinggi yaitu Rp.6500,- dibandingkan dengan menjual karet ke pedagang desa hanya Rp.6000,-. Dengan keuntungan para peserta lelang sebesar Rp. 300 per kg karet kering, di bandingkan dengan Keuntungan yang diterima pedagang desa lebih kecil hanya Rp 150 per kg. hal senada juga dikemukan oleh Hendratno,dkk (1991) bahwa adanya pasar lelang keuntungan bersih yang diterima petani meningkat dan juga pabrik pengolah sedangkan pedagang tingkat desa menurun keuntungannya.

Di pihak pabrik pengolah harus menanggung biaya angkut dan susut, jika membeli di pasar lelang dan jika membeli dari pedagang desa tidak menanggung biaya angkut dan susut, sebab pedagang desa yang membawa hasil dari pembelian karetnya ke pabrik pengolahan.

Adapun saluran pemasaran pada pedagang desa biasanya terpaksa dilakukan oleh para petani yang mempunyai ikatan informal dengan para pedagang desa. Ikatan informal antara pelaku pemasaran ini terjalin karena para pelaku pemasaran tersebut saling membutuhkan dan saling mengenal cukup lama. Ikatan informal tersebut dapat terjadi antara lain (1) Petani / penyadap bagi hasil - pemilik kebun - pedagang desa; (2) Petani - pedagang desa.

Secara historis, ikatan informal dimulai dari adanya kepercayaan para pemilik kebun memberi pekerjaan sebagai sumber mata pencarian bagi para penyadap. Pemilik kebun ini umumnya terikat dengan para pedagang desa yang 
merupakan pedagang kebutuhan sehari-hari yang juga sebagi pedagang karet. Para pemilik kebun ini mendapat kemudahan berupa pinjaman uang untuk perluasan kebun ataupun kredit bahan pangan atau uang untuk keperluan lainnya yang dibayar dengan hasil karetnya.

Keadaan di atas berlangsung terus hingga menjerat para pemilik kebun ke dalam sistem yang diciptakan oleh pedagang desa tersebut dan bagi para pemilik kebun yang tidak terikat dengan hubungan timbal balik tersebut ataupun yang sudah terlepas dari jepitan hutang para pedagang desa, pedagang desa tersebut memberikan insentif kepada para pemilik berupa :

a. Bonus yang cukup besar jika berhasil mengumpulkan karet dalam jumlah yang cukup banyak.

b. Bonus tambahan jika dalam jangka waktu satu tahun mampu memenuhi target karet yang telah ditetapkan oleh para pedagang desa tersebut.

Di satu sisi tampaknya ikatan ini menguntungkan, namun kenyataannya tidaklah demikian karena terdapat gejala bahwa para petanilah yang terkena eksploitasi monopsonistik dari pemilik tersebut dan pedagang desa mereka menjadi tidak leluasa menjual ke tempat lain yang lebih menguntungkan, hal ini dikarenakan pedagang pengumpul yang paling dominan dalam menentukan harga karena langsung membeli ke petani (Suherty, 2003). Para petani umumnya tidak berdaya menghadapi keadaan ini dengan alasan bahwa mereka sudah diberi pekerjaan oleh para pemilik kebun tersebut. Bahkan para pemilik tersebut terkadang tidak lagi memakai para penyadap yang tidak menjual karet kepadanya. Para pedagang tersebut mengambil keuntungan baik dari penjualan barang-barang kebutuhan sehari-hari dan juga dari hasil pembelian karet petani yang dikenakan potongan. Selain itu mereka juga mengambil keuntungan dari tipuan timbangan yang mereka gunakan.

Jika ikatan informal dan berbagai pelayanan tersebut mengalami hambatan dalam menjamin kelancaran pembelian karetnya. Para pedagang desa tersebut akan berusaha meningkatkan harga karet dalam jangka pendek dan jauh melebihi harga 
beli karet dari lembaga pemasaran pesaing tetapi masih menerapkan berbagai 'pinalti' potongan untuk tetap menjamin bahwa penerimaan totalnya tidak mengalami kerugian.

Jika langkah di atas belum juga menjamin kelancaran usaha jual beli karetnya maka langkah selanjutnya adalah menerapkan diskriminasi harga. Diskriminasi harga yang diterapkan adalah dengan cara memberlakukan harga beli karet yang sangat tinggi di suatu daerah/desa untuk mengurangi/mematikan lembaga pemasaran pesaing, dan pedagang sendiri merugi di daerah ini. Hal yang sebaliknya dilakukan di daerah/desa lain yang tidak ada pesaing dengan memberlakukan harga beli karet yang rendah. Penerimaan total dari kombinasi strategi ini, tetap menghasilkan usaha yang tidak merugikan.

\section{Kesimpulan}

Dari penelusuran arus pemasaran karet yang ada di desa Panerokan dapat diketahui bahwa terdapat 2 saluran pemasaran, yaitu : saluran pemasaran KUD/Pasar Lelang dan saluran pemasaran pedagang desa, untuk saluran KUD/Pasar Lelang saat ini menyerap 60,2\% hasil karet sedangkan pedagang desa $39,8 \%$.

Besarnya persentase petani yang menjual karetnya ke pasar lelang, dikarenakan tidak adanya potongan penjualan, seperti yang terjadi pada pedangang desa, sehingga penerimaan petanipun menjadi lebih tinggi dibandingkan jika menjual ke pedagang desa.

Pada saluran pemasaran KUD/Pasar lelang harga yang diterima petani peserta lelang lebih tinggi jika dibandingkan dengan menjual karet ke pedagang desa. Keuntungan bersih peserta lelang lebih besar Rp.300 per Kg karet kering sedangkan keuntungan bersih yang diterima pedagang desa lebih kecil Rp.150 per Kg karet kering. 


\section{Saran}

a. Hendaknya pemerintah daerah berperan dalam mengawasi harga karet yang di pasar lelang dan pedagang desa

b. Sebaiknya petani berusaha menghindari sistem ijon yang dilakukan pedagang desa (menghindari hutang)

c. Bagi KUD sebagai pelaksana lelang hendaknya mengupayakan perbaikan sarana dan prasarana lelang yang berupa penambahan berupa angkutan, penambahan gudang dan peralatan yang modern dengan cara bekerja sama dengan Gapkindo dan pemerintah daerah.

\section{DAFTAR PUSTAKA}

Nasrun, Arbain Hr. (2007) Peranan HKTI Dalam Program Pengembangan Kebun Karet Rakyat Di Indonesia, dialog emas hari ulang tahun Provinsi Jambi ke-50. ALJ-Pakar.

Azzaino,A (1981) Pengantar Tata Niaga Pertanian, Institut Pertanian Bogor (IPB), Bogor.

Bowersox,Donald J dan M. Bixby Cooper (1992), Strategic Marketing Channel Management.Mc.Graw Hill International Singapore.

Dahl, D.C and Hammond. (1977) Market and Price Analysis, McGraw-Hill Book Company, New York.

Hendratno, dkk (1991) Pasar Lelang dan Permasalahannya, Buletin Perkebunan Rakyat, 7 (2), 55 - 62. 
Suherty,Lina .A. Wahib Muhaimin dan Zaenal Fanani (2003) Analisis Efisiensi Pemasaran Jeruk di Kalimantan Selatan. Journal Of Agriculturural Economic, Wacana vol. 6, No 1.

Suhaedi (1986). Pidato Pengarahan pada Lokakarya Usaha Tani Konservasi di Lahan Alang-alang Podsolik Merah Kuning, 11 - 13 Februari 1986 Badan Litbangtang Ditjen Tanaman Pangan, Jakarta.

*) Ahmad Tarmizi, Dosen Jurusan Manajemen, Fakultas Ekonomi, Universitas Batanghari Jambi 